\title{
PROFIL HAMBATAN BELAJAR EPISTIMOLOGIS SISWA PADA MATERI PERSAMAAN KONTINUITAS KELAS XI SMA MELALUI TES KEMAMPUAN RESPONDEN
}

\author{
Raden Hanna Rifani ${ }^{\text {a) }}$, Harun Imansyah ${ }^{\text {b) }}$, Heni Rusnayatic) A. F. C. Wijaya ${ }^{\text {d) }}$ \\ Departemen Pendidikan Fisika, Fakultas Pendidikan Matematika dan Ilmu Pengetahuan Alam, Universitas \\ Pendidikan Indonesia, Jl. Dr. Setiabudhi No. 229, Bandung 40154
}

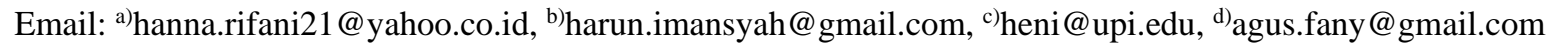

\begin{abstract}
Abstrak
Dalam studi pendahuluan yang telah dilakukan di salah satu SMA di Kota Bandung dengan menggunakan tes dan angket pada materi Persamaan Kontinuitas di dapatkan data angket 60,53\% siswa mengatakan bahwa materi persamaan kontinuitas itu sulit, dan dari hasil tes diperoleh 52,71\% tidak mampu mengerjakan soal persamaan kontinuitas. Tujuan dari penelitian ini adalah untuk mengetahui hambatan belajar siswa dengan menggunakan Tes Kemampuan Responden pada materi Persamaan Kontinuitas pada kelas XI SMA. Hambatan belajar (learning obstacle) yang dikaji adalah hambatan epistimologis yaitu keterbatasan siswa dalam memahami konteks tertentu dalam suatu materi pembelajaran. Penelitian ini dilakukan dengan metode deskriptif kualitatif dengan analisis pendekatan historis melaui bantuan Tes Kemampuan Responden (TKR) yang berbentuk soal uraian yang mencakup materi ensensial dari materi persamaan kontinuitas. Hasil tes tersebut menunjukan bahwa siswa mengalami hambatan epistimologis pada materi persamaan kontinuitas yang mengcakakup tidak memahami fluida ideal yang ditinjau dari jenis alirannya, tidak tepat dalam menentukan besar kecepatan pada luas penampang yang ditanyakan, serta tidak dapat menentukan besar debit pada sebuah kasus.
\end{abstract}

Kata-kata kunci: Hambatan Belajar, Tes Kemampuan Responden, Persamaan Kontinuitas.

\begin{abstract}
In a previous study, which observed and conducted in one of Senior High School in Bandung, using the tests and questionnaires regarding the continuity equation the result shows 60,53\% (from the questionnaire) students answer that the continuity equation is difficult to deal with, and $52,71 \%$ students (test) students could not answer the test. The aim of this study is to know the learning obstacle of students using the respondent capably test in a continuity equation subject for XI high school students. The learning obstacle that has been studied is the epistemological is the limitation of student to understand the certain content of a particular subject. The method used in this study is a descriptive qualitative method using the history analysis approach in Respondent Capability Test. In this approach, the researchers formed questionnaires essay type in which includes the essential sub-subject from continuity equation. The result of the test shows that students are having epistemological learning obstacles in continuity equation, which include the understanding of ideal fluid observed from current type, incorrect in answering the velocity in the cross-sectional area in question, and could not indicate the volume flow rate given case questionnaire.
\end{abstract}

Keywords: Learning obstacles, Respondent capability Test, Continuity equation. 


\section{PENDAHULUAN}

Menurut Undang-undang nomor 20 tahun 2003, pasal 1 ayat 20 ada pengertian pembelajaran yaitu, pembelajaran adalah proses dimana adanya sebuah interaksi yang terjadi antara pendidik dengan peserta didik serta adanya sumber belajar dalam sebuah lingkungan belajar.

Pembelajaran haruslah dilakukan dengan menarik, sehingga peserta didik saat melaksanakan pembelajaran tersebut tidak merasa bosan. Menurut Suryadi (2010) salah satu upaya yang dapat dilakukan pendidik agar bisa meningkatkan kualitas pembelajaran dengan melakukan refleksi kegiatan pembelajaran serta rancangan pembelajaran yang telah dilakukan sebelumnya. Tetapi pada kenyataannya bahwa masih banyak guru yang belum melakukan hal tersebut, sehingga tidak diketahui apakah rancangan yang telah dibuat dan pembelajaran yang telah dilakukan dapat mencapai tujuan pembelajaran atau tidak. Menurut Basar (2004) pengajar fisika masih cenderung membahas teori pembelajaran dari buku pegangan yang digunakan, kemudian hanya memberikan rumus-rumus yang berkaitan lalu memberikan contoh soal. Jarang sekali materi yang diajarkan dikaitkan dengan kehidupan sehari-hari, biasanya ketika pembelajaran fisika dikaitan dengan kasus nyata pada kehidupan sehari-hari siswa akan cenderung lebih bisa memahaminya, dibandingkan hanya diberikan rumus-rumus saja.

Hasil studi pendahuluan yang telah dilakukan di salah satu SMA di kota Bandung dengan menggunakan angket 60,53 \% siswa mengatakan bahwa materi persamaan kontinutas itu sulit, dan dari hasil tes $52,71 \%$ siswa tidak mampu mengerjakan soal persamaan kontinuitas. Berdasarkan hasil studi pendahuluan tersebut siswa ternyata mengalami hambatan epistimologis pada materi persamaan kontinuitas. Tujuan dari penelitian ini adalah untuk mengetahui profil hambatan epistimologis siswa kelas XII SMA pada materi Persamaan Kontinuitas dengan bantuan Tes Kemampuan Responden (TKR). Hambatan belajar adalah situasi dimana siswa menerima informasi yang dianggap benar olehnya tetapi ternyata salah karena keterbatasan pengetahuan yang dimiliki siswa tersebut. Menurut Brousseau (2002) hambatan belajar dibagi berdasarkan sistem (guru-siswa-materi) menjadi tiga yaitu hambatan ontogeni (faktor kesiapan mental siswa), hambatan didaktis (faktor transfer ilmu dari guru kepada siswa), dan hambatan epistimologis (keterbatasan pengetahuan siswa pada konteks tertentu).

Selanjutnya Brousseau mengatakan bahwa jika ingin menentukan hambatan belajar epistimologis pada siswa dapat dilakukan dengan analisis pendekatan historis. Pada buku Thoery of Didactical Situation Brousseau (2002, hal 101) menjelaskan pendekatan historis adalah analisis siswa menjelaskan pengetahuan yang dipelajari, memahami penggunaan pengetahuan yang mereka pelajari, melihat hubungan konsep yang dipelajari dengan konsep-konsep lain yang mungkin berhubungan, mengidentifikasi keadaan permasalahan dan memberikan alasan atas penyelesaian yang diberikan, dan mengulangi respon yang salah pada permasalahan yang sama persis atau mirip, serta bagaimana pemahaman siswa terhadap masing-masing permasalahan

\section{METODE PENELITIAN}

Metode yang digunakan dalam penelitian ini adalah metode kualitatif deskriptif dengan analisis pendekatan historis seperti yang di tulis pada buku Theory of Didactical Situation (2002, hal 101) dengan bantuan Tes Kemampuan Responden (TKR) yang berupa tes tertulis uraian yang berjumlah empat soal yang mencakup materi esensial pada materi Persamaan kontinuitas. Subjek penelitian adalah siswa kelas XII SMA di salah satu SMA di kota Bandung.

\section{HASIL DAN PEMBAHASAN}

Tes Kemampuan Responden (TKR) diberikan kepada siswa kelas XII SMA yang sebelumnya telah mempelajari materi fluida dinamis, dan didapatkan hasil hambatan epistimologis sebagai berikut, 


\section{A. Fluida Ideal Berdasarkan Jenis Alirannya}

Pada materi fluida dinamis, sebelumnya akan dibahas terlebih dahulu mengenai fluida pada kasus ini haruslah dianggap ideal, sehingga siswa harus paham terlebih dahulu apa itu fluida ideal, fluida ideal ini yang akan menjadi perumusan persamaan kontinuitas dan debit.

Tetapi biasanya materi esensial fluida ideal ini tidak dijelaskan secara rinci, siswa biasanya hanya diminta untuk membacanya saja. Sehingga siswa hanya menghapal pengertian dari jenis-jenis aliran fluida ideal tersebut, tanpa tahu bahwa dengan adanya syarat fluida ideal itu akan merumuskan persamaan kontinuitas fluida yang mengalir pada sebuah penampang, dan juga berhubungan dengan konsep debit. Jadi materi pada fluida dinamis ini saling berkaitan satu sama lainnya. Berikut ini adalah hasil tes yang telah diberikan kepada siswa berkaitan dengan fluida ideal.

TABEL 1. Hambatan epistimolgis peserta didik pada konsep esensial Fluida Ideal Berdasarkan Jenis Alirannya

\begin{tabular}{|c|c|c|}
\hline Coding & Keterangan & Persentase \\
\hline \multirow{4}{*}{1} & $\begin{array}{l}\text { Tidak dapat menjelaskan aliran tak-termampatkan } \\
\text { (incompresibel) yaitu fluida tidak akan mengalami } \\
\text { perubahan volume ketika diberi tekanan. }\end{array}$ & $89,18 \%$ \\
\hline & $\begin{array}{l}\text { Tidak dapat menjelaskan aliran fluida yang tunak itu } \\
\text { kecepatannya sama (konstan) di setiap titik pada waktu } \\
\text { kapanpun. }\end{array}$ & $100 \%$ \\
\hline & $\begin{array}{l}\text { Tidak dapat menjelaskan aliran tak-kental (non-viscos) } \\
\text { itu tidak mengalami gesekan dengan sesama partikel } \\
\text { fluida ataupun dengan tempat fluida mengalir, sehingga } \\
\text { tidak terjadi disipasi energi. }\end{array}$ & $97,29 \%$ \\
\hline & $\begin{array}{l}\text { Tidak dapat menjelaskan aliran laminar adalah aliran } \\
\text { garis alirnya lurus dan jelas. }\end{array}$ & $97,29 \%$ \\
\hline
\end{tabular}

Pada soal nomor 1, ditanyakan pengetian serta penjelasan dari jenis aliran fluida ideal yaitu incompressible, non-viscos, tunak, dan laminar. Siswa tidak dapat menjelaskan apa yang di perintahkan pada soal. Hambatan epistimologis $100 \%$ muncul pada coding $1 \mathrm{~b}$, yaitu siswa tidak bisa menjelaskan pengertian dari fluida ideal yang memiliki aliran tunak. Siswa tidak dapat menjelaskan bahwa tunak adalah aliran fluida pada suatu titik tertentu akan memiliki kecepatan dana rah aliran yang konstan pada waktu kapanpun, jika siswa paham akan sifat-sifat fluida ideal ini maka siswa akan paham konsep esensial selanjutnya yaitu persamaan kontinuitas. Berikut adalah salah satu contoh bahwa siswa tidak bisa menjelaskan fluida ideal yang memiliki sifat tunak.

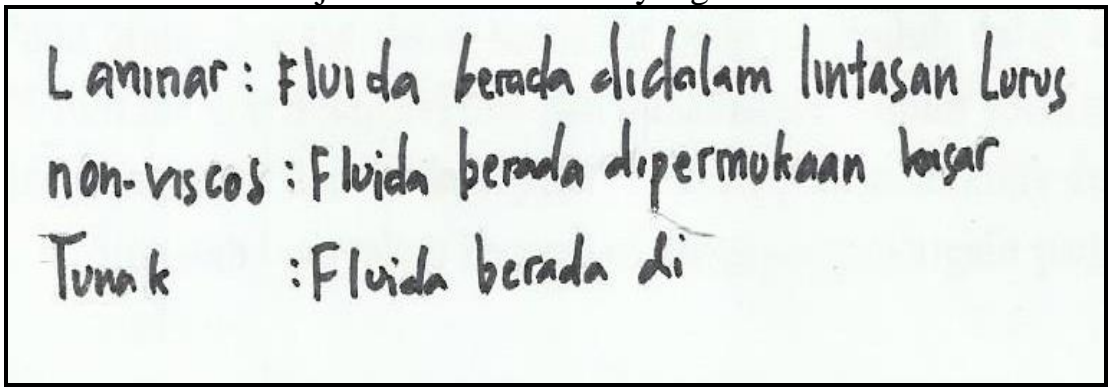

GAMBAR 1. Jawaban salah satu siswa untuk instrument tes no 1

\section{B. Persamaan Kontinuitas}

Ketika siswa sudah paham mengenai konsep esensial fluida ideal, maka siswa juga tidak akan kesulitan dalam memahami materi pada konsep esensial persamaan kontinuitas. Berikut adalah data hasil tes yang diberikan kepada siswa berkaitan dengan konsep esensial persamaan kontinuitas. 
TABEL 2. Hambatan epistimolgis peserta didik pada konsep esensial Persamaan Kontinuitas

\begin{tabular}{|c|c|c|}
\hline Coding & Keterangan & Persentase \\
\hline \multirow{7}{*}{2} & $\begin{array}{l}\text { Keliru mengidentifikasi besaran fisis pada konsep } \\
\text { persamaan kontinuitas }\end{array}$ & $60,35 \%$ \\
\hline & $\begin{array}{l}\text { Keliru mengidentifikasi satuan untuk besaran fisis pada } \\
\text { konsep persamaan kontinuitas }\end{array}$ & $60,35 \%$ \\
\hline & $\begin{array}{l}\text { Kurang tepat dalam menuliskan persamaan kontinuitas } \\
\text { yang sesuai dengan kasus yang tertera pada soal. }\end{array}$ & $59,45 \%$ \\
\hline & $\begin{array}{l}\text { Kurang tepat dalam mengoperasikan satuan fisis yang } \\
\text { diketahui ke dalam persamaan kontinuitas. }\end{array}$ & $90,08 \%$ \\
\hline & $\begin{array}{l}\text { Kurang tepat dalam menentukan besar kecepatan pada } \\
\text { luas penampang yang ditanyakan }\end{array}$ & $90,08 \%$ \\
\hline & $\begin{array}{l}\text { Kurang tepat dalam memberikan satuan pada besar } \\
\text { kecepatan pada luas penampang yang ditanyakan }\end{array}$ & \\
\hline & $\begin{array}{l}\text { Tidak dapat menjelaskan makna fisis dari persamaan } \\
\text { kontinuitas }\end{array}$ & $59,45 \%$ \\
\hline
\end{tabular}

Pada tabel 2 hambatan epistimologis pada konsep esensial persamaan kontinuitas yang paling besar muncul pada koding $2 \mathrm{~d}$ dan $2 \mathrm{e}$ sebesar 90,08\% yaitu siswa memiliki hambatan dalam mengoperasikan satuan fisis yang diketahui ke dalam persamaan kontinuitas dan serta dalam menentukan besar kecepatan pada luas penampang yang ditanyakan. Maksud dari koding ini adalah untuk mengetahui pemahaman siswa terhadap konsep persamaan kontinuitas. Ketika dalam soal diketahui diameter dua luas penampang yang berbeda ukuran dan di dalamnya mengalir sebuah fluida, pada soal tersebut menanyakan besar kecepatan salah satu fluida di salah satu luas penampang. Ketika akan mencari besar kecepatan fluida pada salah satu luas penampang maka siswa yang tidak mengalami hambatan epistimologis akan menggunakan persamaan, $A_{1} v_{1}=A_{2} v_{2}$. Pada soal tertera data diameter, sehingga untuk mencari kecepatan pada salah satu penampang data diameter tersebut digunakan untuk mencari luas penampang dimana fluida itu mengalir, pada soal luas penampangnya adalah lingkaran, sehingga data diameter seharusnya digunakan untuk mencari luas lingkaran yaitu $A=\frac{1}{4} \pi d^{2}$, maka persamaan kontinuitas bisa berubah menjadi $d_{1}{ }^{2} v_{1}=d_{2}{ }^{2} v_{2}$. Ternyata siswa mengalami hambatan dalam mengubah nilai diameter ke luas penampang, seperti pada gambar di bawah ini, 


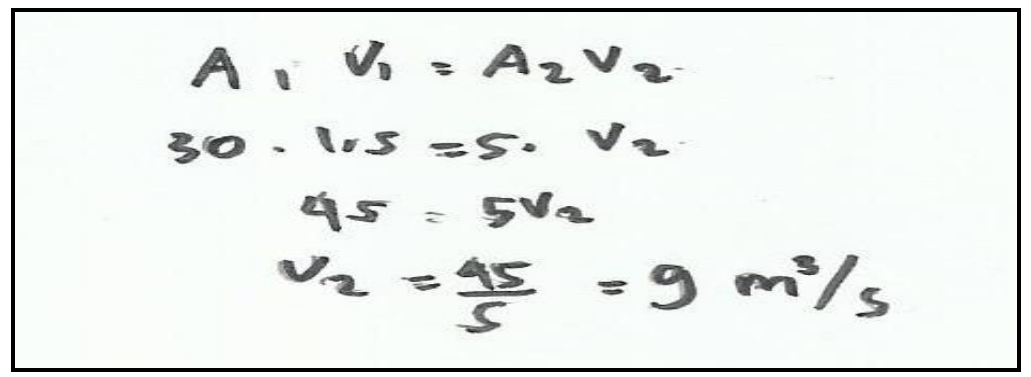

GAMBAR 2. Jawaban salah satu siswa untuk intrumen no 2a

Dapat dilihat siswa langsung memasukan nilai diameter pada persamaan $A_{1} v_{1}=A_{2} v_{2}$ sehingga nilai kecepatan yang ditanyakan hasilnya tidak tepat. Begitupun untuk menentukan satuan pada kecepatan pada gambar di atas siswa masih kurang tepat dalam memberikan satuan kecepatan, hal ini juga meruapakan hambatan yang muncul walaupun nilai persentase hambatannya tidak sebesar koding $2 \mathrm{~d}$ dan $2 \mathrm{e}$.

\section{Debit}

Konsep esensial debit ini sangat berkaitan dengan konsep esensial persamaan kontinuitas, Berikut ini adalah hasil tes yang telah diberikan kepada siswa berkaitan dengan konsep esensial debit.

TABEL 3. Hambatan epistimolgis peserta didik pada konsep esensial Debit

\begin{tabular}{|c|c|c|}
\hline Coding & Keterangan & Persentase \\
\hline \multirow{6}{*}{3} & $\begin{array}{l}\text { Keliru mengidentifikasi besaran yang ditanyakan } \\
\text { pada soal }\end{array}$ & $66,21 \%$ \\
\hline & $\begin{array}{l}\text { Kurang tepat dalam menuliskan persamaan debit } \\
\text { yang sesuai dengan kasus yang ditanyakan pada soal }\end{array}$ & $68,92 \%$ \\
\hline & $\begin{array}{l}\text { Kurang tepat dalam mengoperasikan satuan fisis yang } \\
\text { diketahui ke dalam persamaan debit }\end{array}$ & $95,94 \%$ \\
\hline & $\begin{array}{l}\text { Kurang tepat dalam menentukan besar debit pada } \\
\text { kasus yang ditanyakan pada soal }\end{array}$ & $95,94 \%$ \\
\hline & $\begin{array}{l}\text { Kurang tepat dalam menentukan satuan pada besaran } \\
\text { fisis debit }\end{array}$ & $85,14 \%$ \\
\hline & $\begin{array}{l}\text { Tidak dapat menjelaskan makna fisis dari konsep } \\
\text { debit }\end{array}$ & $81,08 \%$ \\
\hline
\end{tabular}

Pada tabel 3 muncul hambatan epistimologis paling besar pada koding 3c dan 3d yaitu sebesar $95,94 \%$. Dalam soal tes ada dua soal yang menanyakan besar debit yaitu pada instrument no 3 dan 4 , soal no 3 menanyakan besar debit aliran darah pada suatu pembuluh darah, dan soal no 4 adalah mencari debit fluida yang mengalir pada dua pipa yang memiliki luas penampang yang berbeda. Pada soal mencantumkan besar diameter tempat fluida itu mengalir dan diketahui salah satu kecepatan fluida di salah satu luas penampang. Debit adalah jumlah fluida yang mengalir yaitu sebanyak $\mathrm{m}^{3}$ dalam satuan waktu atau dapat di tulis $Q=\frac{V}{t}$ atau $Q=A$.v. Jika siswa tidak mengalami hambatan epistimologis pada persamaan kontinuitas maka siswa tidak akan mengalami hambatan epistimologis pada konsep debit. Persamaan kontinuitas kita tahu persamaannya adalah $A_{1} v_{1}=A_{2} v_{2}$, maka ini 
sama halnya dengan $Q_{1}=Q_{2}$. Siswa masih menganggap bahwa konsep persamaan kontinuitas dengan konsep debit itu berbeda. Berikut ini adalah contoh jawaban siswa untuk instrument no $3 b$ dan no 4.

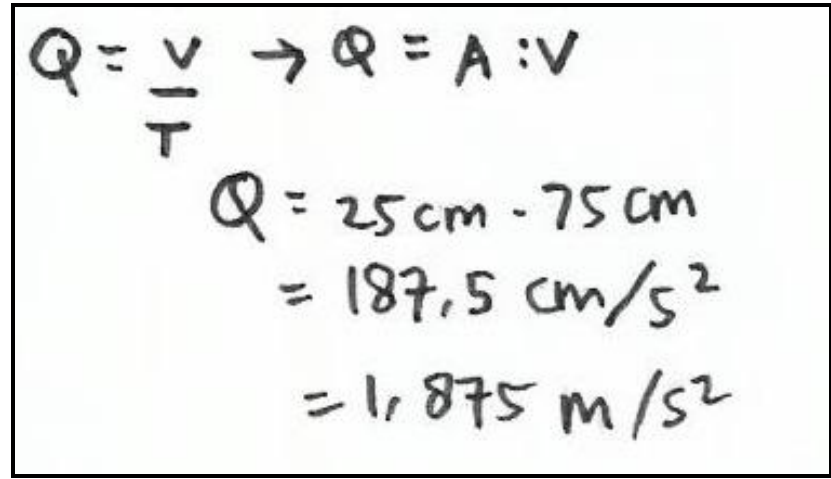

GAMBAR 3. Jawaban siswa untuk instrument no 3a

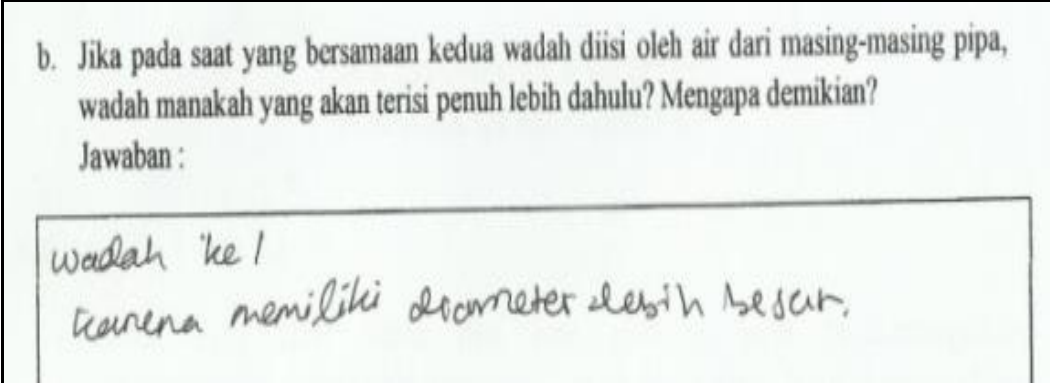

GAMBAR 4. Jawaban siswa untuk instrument no 4b

Pada soal no 3 b siswa diminta untuk mencari nilai debit pada pembuluh darah, di dalam soal nilai diameter adalah data yang diberikan, sedangkan untuk mencari debit ada dua persamaan yang dapat kita gunakan yaitu $Q=\frac{V}{t}$ atau $Q=A$. v. Pada gambar (3) siswa menggunakan persamaan $Q=A$. $v$ untuk mencari nilai debit yang ditanyakan, tetapi siswa tidak mengubah nilai diameter menjadi nilai luas penampang, siswa langsung memasukan nilai diameter pada persamaan $Q=A \cdot v$ sehingga besar debit yang ditanyakan nilainya tidak tepat, dikarenakan siswa mengalami hambatan pada koding $3 \mathrm{c}$ dan 3d.

Pada instrumen no 4b ditanyakan ember yang mana yang akan terisi penuh lebih dulu ketika kedua ember dengan kapasitas yang sama diisi dari dua keran yang berbeda ukuran, tetapi mengalirkan air dari sumber yang sama. Jawaban yang tepat tentu saja kedua ember akan terisi penuh secara bersamaan karena memenuhi persamaan $Q_{1}=Q_{2}$ degan syarat sumber air dari tempat yang sama kemudian air dialirkan melalui dua keran yang berbeda ukurannya. Tetapi siswa masih mengira bahwa keran yang memiliki diameter yang lebih besar akan mengeluarkan air lebih banyak, seperti pada jawaban salah satu siswa diatas pada gambar (4). Hal ini merupakan hambatan epistimologis juga yaitu termasuk pada koding $3 \mathrm{f}$, tetapi besar hambatan yang muncul tidak sebesar pada koding $3 \mathrm{c}$ dan $3 \mathrm{~d}$.

\section{SIMPULAN}

Dapat disimpulkan hambatan epistimologis yang muncul adalah pada konsep esensial fluida ideal yang muncul tidak dapat menjelaskan aliran fluida yang tunak itu yang memiliki kecepatan tetap (konstan) di suatu titik pada waktu kapanpun sebesar 100\%, pada konsep esensial persamaan kontinuitas hambatan epistimologis yang muncul adalah kurang tepat dalam mengoperasikan satuan fisis yang diketahui ke dalam persamaan kontinuitas dan kurang tepat dalam menentukan besar kecepatan pada luas penampang yang ditanyakan sebesar 90,08\%, dan pada konsep esensial debit hambatan epistimologis yang muncul yaitu kurang tepat dalam mengoperasikan satuan fisis yang 
diketahui ke dalam persamaan debit dan kurang tepat dalam menentukan besar debit pada kasus yang ditanyakan pada soal sebesar $95,94 \%$. Sehingga ada upaya yang dapat dibuat untuk meminimalisir besar hambatan epistimologis siswa pada materi persamaan kontinuitas.

\section{UCAPAN TERIMAKASIH}

Terimakasih kepada pak Harun Imansyah, Ibu Heni Rusnayati, dan Pak Agus Fany selaku pembimbing I, II dan III yang telah membantu dalam menyelesaikan paper ini. Kemudian kepada rekan-rekan seperjuangan tim DDR yaitu Yunia, Gita, Arif dan Kartika. Tidak lupa kepada kedua orang tua saya dan kakak-kakak saya yang telah membantu memberikan dukungan moril dan juga materil selama proses pembuatan paper ini, dan tidak lupa untuk sahabat-sahabat Jeannyka A.J, Dita Hidayanti, dan Gusyani yang selalu memberikan dukungan semangat selama pembuatan paper ini.

\section{REFERENSI}

[1] Basar, K. (2004). Mengkaji Kembali Pengajaran Fisika di Sekolah Menengah (SMP dan SMA) di Indonesia. [Online]. Tersedia : http://io.ppijepang.org/old/articel.php?id=/45.

[2] Brousseau, G. Theory of Didactical Simulations in Mathematics. New York: Kluwer Academic Publisher, 2002.

[3] Dahar, Ratna Wilis. Teori-teori Belajar dan Pembelajaran. Jakarta : Erlangga, 2011.

[4] Nusantara, Fauzan. Desain Didaktis Konsep Usaha kelas XI SMA Berdasarkan Analisis Kesulitan Belajar Siswa. Skripsi, Universitas Pendidikan Indonesia. 2015

[5] Havid, Muhammad. Desain Didaktis Pembelajaran Konsep Torsi Dan Momen Inersia Berdasarkan Analisis Kesulitan Belajar Siswa Kelas XI SMA. Skripsi, Universitas Pendidikan Indonesia. 2016.

[6] Suryadi, D. Metapedadidaktik dan didactical design research (DDR) sintesis hasil pemikiran berdasarkan lesson study. Teori, Paradigma, Prinsip, dan Pendekatan Pembelajaran MIPA dalam Konteks Indonesia. Bandung, FPMIPA UPI, hal 55-75, 2010.

[7] Undang-Undang Republik Indonesia Nomor 20 Tahun 2003 tentang Sistem Pendidikan Nasional. 
